\title{
Okul Öncesi Kaynaştırma Sınıflarındaki Öğretmenlerin, Özel Gereksinimli ve Risk Grubu Çocukların Sınıf İçi Davranışlarının İncelenmesi*
}

\author{
Şeyda Demir ${ }^{* *}$ \\ Ankara Üniversitesi
}

Öz

Okul öncesinde kaynaştırma uygulamaları, birçok uzman ve öğretmen tarafından özel gereksinimli (ÖG) çocuklar için en iyi uygulamalar olarak görülmektedir. Ancak okul öncesi sınıflarda çalışan öğretmenler ve sınıflarındaki ÖG çocukların davranışlarının gözlemlendiği araştırmalar sınırlı sayıdadır. Bu nedenle araştırmanın amac1, sınıfinda ÖG ve öğretmen görüşlerine göre risk grubu (RG) olduğu düşünülen çocuk olan okul öncesi öğretmenlerinin ve bu çocukların sınıf içi davranışlarının incelenmesidir. Betimsel bir araştırma olan bu çalışmada, Ankara'da bağımsız bir anaokulunda çalışan on yedi okul öncesi öğretmeni ile sınıflarındaki ÖG ya da RG çocukların davranışları, masa başı etkinlikler (MBE) ve serbest zaman etkinliklerinde (SZE) yarımşar saat kamera ile kaydedilmiştir. Video kayıtları, geliş̧tirilen gözlem kayıt formları ile izlenmiş; böylece öğretmen ve ÖG ya da RG çocuk davranışları değerlendirilmiştir. Gözlem sonuçları, öğretmenlerin MBE ve SZE'de ÖG ya da RG çocukla benzer şekilde etkileşim kurduğunu, her iki etkinlikte de ÖG ya da RG çocuğa yönelik benzer sayıda olumlu davranış sergilediğini, olumsuz davranışlarının çok az olduğunu göstermiştir. ÖG ya da RG çocuklar ise akranlarıyla SZE'de MBE'ye oranla daha çok etkileşim kurmuşlar, SZE'de akranları ve öğretmenleriyle olumlu etkileşimlerinin sıklı̆̆ MBE'ye göre biraz daha fazla olmuştur. Her iki etkinlikte de akranları ve öğretmenlerine yönelik olumsuz etkileşim sıklıklarının da benzer olduğu görülmüştür. Ayrıca hem MBE hem de SZE için problem davranışlarının oranı benzer bulunmuş, çocukların MBE'nin yarısına yakınında verilen görev üzerinde çalıştıkları belirlenmiş̧ir. Bulgular ilgili alanyazın çerçevesinde tartışılmıştır.

Anahtar sözcükler: Kaynaştırma/bütünleştirme, okul öncesi sınıflar, sınıf içi öğretmen ve çocuk davranışları, gözlem

\footnotetext{
*Bu çalışma, yazarın Ankara Üniversitesi Eğitim Bilimleri Enstitüsü’nde, Prof. Dr. N. Bülbin Sucuoğlu danışmanlığında tamamlamış olduğu doktora tez çalışmasından üretilmiştir. Çalışma, Ankara Üniversitesi BAP Birimi tarafindan desteklenen 12B605002 no'lu projenin bir kısmından oluşmaktadır.

${ }^{* *}$ Sorumlu Yazar: Arş. Gör. Dr., Ankara Üniversitesi, Eğitim Bilimleri Fakültesi, Özel Eğitim Bölümü, Ankara. E-posta: sedemir@ankara.edu.tr
} 


\title{
In-Class Behaviors of Teachers and Children with Special Needs or Risk Group in Inclusive Preschool Classrooms
}

\begin{abstract}
Preschool inclusion is seen as the best practice for children with special needs (SN) by experts and teachers. However there are limited number of studies in which behaviors of teachers working in preschool inclusive classrooms and behaviors of their students with $\mathrm{SN}$ are observed. The purpose of this study was to examine the behaviors of teachers working in preschool inclusive classrooms and behaviors of their students with SN or children who are risk group (RG). This is a descriptive research study in which behaviors of seventeen preschool teachers and their students with SN or RG from one public preschool in Ankara, Turkey, were video recorded during thirty minute table-top activities (TTA) and thirty minute free play (FP). Video records were analyzed using observation forms developed. Analyses of the observations revealed that teachers were interacting more or less at the same rate with children with SN or RG in TTA and FP, positive behaviors directed at children with SN or RG were almost the same during both activities, and teachers' negative behaviors were very few. Children with SN or RG were interacting with their peers more during FP than TTA, positive interactions with peers and teachers were a little more in FP than TTA. Negative interactions with peers and teachers were almost same in both activities. Moreover problem behaviors were almost same for both activities, and children with SN and RG engaged in on-task behaviors almost half of the TTA. Results are discussed in the framework of the current literature.
\end{abstract}

Keywords: Mainstreaming/inclusion, preschool classrooms, teacher and student in-class behaviors, observation

Okul öncesinde kaynaştırma uygulamaları, birçok uzman ve öğretmen tarafından özel gereksinimli (ÖG) çocuklar için en iyi uygulamalardan biri olarak kabul edilmektedir (Henninger ve Gupta, 2014; Odom ve McEvoy, 1990). Bunun sebebi, erken dönemde kaynaştırma uygulamaları yürütülen sınıfların en az kısıtlayıcı çevre olmasıdır (File ve Kontos, 1992). En az kısıtlayıcı çevre, ÖG çocukların normal gelişim gösteren akranlarıyla en üst düzeyde birlikte olabilecekleri ve öğretimden en iyi şekilde yararlanabilecekleri ortamlardır (Individuals with Disabilities Education Act [IDEA], 2004).

Sosyal beceri ve etkileşimlerindeki yetersizlikler, etkinliklere katılımlarındaki güçlükler ile problem davranışlarının normal gelişen akranlarından fazla olması ÖG çocukların ortak özellikleri olarak kabul edilebilir. $\mathrm{Bu}$ çocukların problem davranışları, normal gelişim gösteren akranlarından 3-4 kat daha fazladır (Baker, Blacher, Crnic ve Edelbrock, 2002). Bu davranışlar ÖG çocukların yeni beceriler öğrenmelerini, olumlu sosyal etkileşimler ve arkadaşlıklar kurmaları (Erbaş, Kırcaali-İftar ve Tekin-İftar, 2004) ile öğretmenleriyle etkileşimlerini olumsuz etkilemektedir (Jack ve diğ., 1996). Okul öncesi sınıflarda ÖG çocukların genellikle sınıf düzenini bozan ve kendilerine ya da çevrelerine zarar veren davranışlar sergiledikleri bilinmekte (Allen ve Cowdery, 2015), öğretmenler de özellikle sınıf düzenini bozan davranışlarla baş etmekte zorlanmaktadırlar (Arnold, McWilliams ve Arnold, 1998). Problem davranışların çok sık sergilendiği sınıflarda öğretmenler, bu davranışlarla baş etmek için genellikle, davranışlar ortaya çıktıktan sonra azaltılmasına yönelik olan ve çoğunlukla olumsuz davranışların sergilenmesini gerektiren tepkisel (reactive) yöntemleri kullanmaktadırlar (Conroy ve Brown, 2004). Problem davranışların önlenmesini ve çocukların istendik davranışlarına olumlu tepkiler verilmesini içeren önleyici (proactive) yöntemler yerine tepkisel yöntemleri kullanan öğretmenlerin stres düzeyleri artmakta, ÖG çocukların ise görev üzerinde çalışma süreleri azalmaktadır (Clunies-Ross, Little ve Kienhuis, 2008). 
VE RISK GRUBU ÇOCUKLARIN SINIF IÇİ DAVRANIŞLARININ INCELENMESI

ÖG çocukların problem davranış sergileme olasılığını artıran bazı faktörler bulunmaktadır. Örneğin sosyal etkileşim becerilerinin sınırlı olması ÖG çocukların problem davranışlarını artırabilmekte (Craig-Unkefer ve Kaiser, 2002), çocukların nasıl etkileşim başlatacaklarını ya da diğerlerinin etkileşim başlatmalarına nasıl tepki vereceklerini bilmemeleri de, kendi gereksinimlerini ve isteklerini akranlarına ifade etmekte güçlük yaşamalarına, akranları tarafından reddedilmelerine ve daha fazla problem davranış sergilemelerine yol açabilmektedir. ÖG çocukların sosyal etkileşim davranışları akranlarından farklılaşmakta (Porter, 2002), akranlarıyla kurdukları etkileşimlerin basit düzeyde olduğu, etkileşim başlatmada zorlandıkları ve sosyal etkileşimlerden kaçındıkları (Merrell ve Holland, 1997), akranlarıyla olumsuz etkileşimler kurdukları ve etkileşim başlatma girişimlerine de genellikle olumsuz tepkiler aldıkları bilinmektedir (Guralnick, 1999). Özellikle okul öncesi dönemde çocukların akranlarıyla kurdukları etkileşimler, arkadaşlık ilişkileri oluşturabilmeleri için çok önemli bir faktördür (Guralnick, 2001).

ÖG çocukların problem davranışlarının akranlarından fazla olması ve sosyal etkileşim davranışlarındaki sınırlılıklarına ek olarak, sınıf içi etkinliklere ve akran etkinliklerine katılım (engagement) ile ilgili güçlükleri olduğu bilinmektedir (McWilliam ve Bailey, 1995). Katılım, bireyin çevresindeki kişiler, materyaller ve etkinliklerle bağlamsal (contextual) açıdan ve gelişim düzeyine uygun şekilde etkileşim kurma anlamına gelmektedir (McWilliam, Trivette ve Dunst, 1985). Bilişsel becerilerdeki sınırlılıklar ve motor beceri yetersizlikleri, ÖG çocukların akranlarına ve etkinliklere katılımını olumsuz şekilde etkilemektedir (McWilliam ve Bailey, 1995). Diğer taraftan okul öncesi sınıflarda çocuklar pek çok kavram ve beceriyi yapılandırılmış etkinlikler olan masa başı etkinliklerde (MBE) öğrenmekte, bilişsel ve motor becerilerdeki yetersizlikler çocukların etkinliklere katılımlarını ve dolayısıyla öğrenmelerini olumsuz etkileyebilmektedir (McWilliam ve Bailey, 1995). MBE’ye katılım süresi, bir başka deyişle görev üzerinde çalışma davranışlarının artması çocukların gelişimlerini de olumlu yönde etkilemektedir (Karnes, Johnson, Cohen ve Shwedel, 1985). Benzer şekilde ÖG çocukların akranlarıyla serbest zaman etkinliklerine katılmaları, serbest zamanda etkileşime girmeleri ve oyun oynamaları sosyal bütünleştirmenin sağlanmasında en önemli öğelerdendir (Bossaert, Colpin, Pijl ve Petry, 2011). Ayrıca ÖG çocukların bu etkinlikler sırasındaki sosyal etkileşimleri, akran kabulü için de çok önemli olmasına karşın ÖG çocukların sosyal etkileşim becerilerini öğrenmeleri için müdahaleye gereksinimleri olabilmektedir (Bronson, Hauser-Cram ve Erickson-Warfield, 1995).

Okul öncesi öğretmenlerinin ÖG çocuklarla kurduğu etkileşimler çocukların gelişimini önemli ölçüde etkilemekte (Birch ve Ladd, 1998; Hughes, Cavell ve Willson, 2001), ayrıca çocukların akranlarıyla etkileşim kurmalarını da kolaylaştırmaktadır (Hestenes ve Carroll, 2000). Ancak, öğretmenlerin çocukların istendik davranışları için çok az ödül ya da övgü kullanmaları, problem davranışları için tepkisel yöntemleri tercih etmeleri ya da çocukların davranışlarını çok sık eleştirmeleri, öğretmen-çocuk etkileşimlerini, dolayısıyla da sınıfın öğrenme ortamını olumsuz şekilde etkilemektedir (Hutchings ve diğ., 2007). Örneğin, Gunter ve Jack (1994), duygusal ve davranışsal bozukluğu olan çocukların problem davranışlarının öğretmenlerin sınıf içi davranışları üzerindeki etkisini incelemişler, sınıfta geçirilen sürenin \%22'sinde öğretmenlerin problem davranışı olan çocuklara olumsuz görüşler bildirdikleri konuşmalar gerçekleştirerek olumsuz etkileşim kurdukları gözlenmiştir. Gözlem yapılan sürenin yalnızca \%3'ünde öğretmenler, problem davranış sergileyen çocuklara övgü sunmak gibi olumlu etkileşim davranışları sergilemişlerdir. Shores ve Wehby (1999) de öğretmenlerin problem davranış sergileyen çocuklara övgü ya da sosyal pekiştireç kullanımının çok az olduğunu, öğretmenlerin öğretim yapmanın zor olduğunu düşündükleri çocuklarla sınıf içinde etkileşim kurmaktan kaçındıklarını ortaya koymuşlardır.

Kaynaştırma ortamlarında çalışmak, öğretmenlerin rollerini farklılaştırmakta ve farklı özellikleri olan çocukların gereksinimlerini aynı ortamda karşılamaları beklenmektedir. Öğretmenler kaynaştırma düşüncesini ve ÖG olan çocukların akranlarıyla aynı ortamda olmalarını kabul etseler de (Eiserman, Shisler ve Healey, 1995; Gal, Schreur ve Engel-Yeger, 2010; Parker, 2011), bu çocukların gereksinimlerini karşılamak konusunda eğitimlerinin ve deneyimlerinin yetersiz olduğunu ifade etmektedirler (Akalın, Demir, Sucuoğlu, Bakkaloğlu ve İşcen, 2014; Bruns ve Mogharberran, 2007; Crane-Mitchell ve Hedge, 2007; Sharma, Um, Forlin, Loreman ve 
Earle, 2006). Öğretmenler ÖG çocuklar için okul programında ve etkinliklerde uyarlama yapmakta zorlanmakta, problem davranışlarla baş edememekte ve ÖG çocukları sınıf etkinliklerine katamamaktadırlar (Akalın ve diğ., 2014). Özellikle ÖG çocukların problem davranışlarının azaltılmasına yönelik yöntemlere ilişkin bilgilerinin sinırlı olduğunu belirten öğretmenler (Buell, Hallam, Gamel-McCormick ve Scheer, 1999), problem davranışların azaltılması ve kaynaştırma ortamlarında sınıf yönetimi konusunda bilgi ve beceri gereksinimlerinin olduğunu sıklıkla vurgulamaktadırlar (Akalın ve diğ., 2014; Gettinger, Stoiber, Goetz ve Caspe, 1999). Ayrıca öğretmenler, çocukların yetersizlik düzeyleri ve problem davranışları arttıkça özel eğitim sınıflarında eğitim almaları gerektiğini düşünmektedirler (Gemmel-Crosby ve Redditi-Hanzlik, 1994; MacFarlane ve Woolfson, 2013).

Hammarberg (2003), öğretmenlerin problem davranışların sık görüldüğü sınıflarda enerji ve zamanlarını bu davranışları azaltmak için harcadıklarını bu davranışları sergileyen çocuklara olumsuz duygular hissederek, bu davranışlarla baş etmekte zorlandıklarında sınıf yönetimi becerilerinin zayıf olduğunu düşünüp kendilerini yetersiz hissettiklerini belirtmektedir. Stanton-Chapman ve Brown (2015) ise öğretmenlerin, ÖG olan ve olmayan çocuklara sosyal becerileri öğretmek için eğitim almaları gerektiğini belirtirken, Chang, Shih ve Kasari (2016) ise, akranlar arasındaki sosyal etkileşimleri artıracak stratejileri çok az kullanmakta olduklarını ifade etmektedirler. Ayrıca, Sucuoğlu, Bakkaloğlu, Akalın, Demir ve İşcen-Karasu (2015) çalışmalarında, öğretmenlerin ÖG çocuklarla sınıf içindeki etkileşimlerinin sınırlı olduğunu bulmuşlar; Jack ve diğerleri (1996) de öğretmenlerin problem davranış sergileyen çocuklarla daha az olumlu etkileşim kurduklarını vurgulamışlardır. Tüm bu etmenler göz önüne alındığında öğretmenler ÖG çocukları sınıflarında istememekte, ÖG çocukların kaynaştırılmasına ilişkin olumsuz tutumlar sergilemektedirler (Dias ve Cadime, 2016; GemmelCrosby ve Redditi-Hanzlik, 1994; Huang ve Diamond, 2009).

Türkiye'de yapılan çalışmalarda ilkokulda genel eğitim sınıflarına devam eden ÖG çocukların ve öğretmenlerinin sınıf içi davranışları birkaç çalışmada incelenmiştir (Akalın, 2007; Çifci, Yıkmış ve AkbabaAltun, 2001; Güner-Yıldız, 2015; Sazak-Pınar ve Güner-Yıldız, 2013). Buna karşın özel gereksinimli çocukların bulunduğu okul öncesi sınıflarındaki ÖG çocukların ve öğretmenlerinin davranışlarına ilişkin tek çalışma bulunmaktadır. Bu çalışmada (Sucuoğlu ve diğ., 2015), Sucuoğlu ve diğerlerinin öğretmenler için geliştirdiği Okul Öncesi Öğretmen Eğitimi Programının öğretmenlerin bilgileri, tutumları, sınıf yönetimleri yanı sıra ÖG çocuklara yönelik sınıf içi davranışları üzerinde etkili olup olmadığı, eğitim programı sonrasında öğretmen davranışlarının değişip değişmediği incelenmiştir. Yapılan analizler sonucunda sadece birkaç öğretmen davranışında anlamlı değişme olduğu, öğretmenlerin eğitim sonrasında diğer çocuklarla daha az etkileşime girdikleri ve ÖG çocuğun sosyal davranışlarını daha az ödüllendirdikleri bulunmuştur. Diğer taraftan ön ve son değerlendirmeler arasında anlamlı fark çıkmasa da öğretmenlerin özel gereksinimli çocukla etkileşim davranışları MBE ve SZE'de artmıştır. Bu bulgular okul öncesi öğretmen davranışlarının daha ayrıntılı incelenmesi gerektiğini düşündürmüştür. Ayrıca bu çalışmada çocuk davranışları incelenmemiştir. Oysa araştırmalar öğretmen davranışları ile ÖG çocukların olumlu ve olumsuz davranışlarının doğrudan ilişkili olduğunu (Greenwood ve Carta, 1987) ve öğretmenlerin sınıf içi davranışlarının çocuk davranışlarını etkilediğini ortaya koymuştur (Marzano ve Marzano, 2003). Bu nedenle öğretmen davranışları incelenirken çocuk davranışlarının da incelenmesi önemli görülmektedir (Guskey, 2014). Ayrıca öğretmenlerin sınıflarındaki çocukları değerlendirmede ve değerlendirme sonuçlarına göre öğretimi uyarlama gibi önemli kararları almada yetkin oldukları (Cotton, 1988); bu nedenle çocukların sınıf içi performanslarına göre ileride ÖG tanısı alma olasılığı bulunan bir başka deyişle risk grubu (RG) çocukları belirlemede güvenilir, nesnel ve önemli kaynaklar oldukları ileri sürülmektedir (McDermott, 1993). Okul öncesi sınıflardaki ÖG çocukların ve öğretmenlerinin sınıf içi davranışlarının incelenmesi, hem kaynaştırma sınıflarında her iki grubun davranışlarının belirlenmesini sağlayacak, hem de öğretmen ve çocuklar için geliştirilecek müdahale programlarının içeriğine ilişkin bilgi sağlayacaktır. Bir başka deyişle sadece ÖG çocuğun değil, okul öncesi öğretmeninin de hangi davranışlarına odaklanılması gerektiği ve müdahale programlarının hangi davranışlar üzerindeki etkilerinin araştırılması gerektiği konusunda da bilgi sağlanmış olacaktır. Bu noktadan hareketle bu araştırmanın amacı, sınıfında ÖG ya 
da RG çocuk bulunan okul öncesi öğretmenlerinin ve sınıflarındaki ÖG ya da RG çocukların sınıf içi davranışlarının incelenmesidir. Bu genel amaç doğrultusunda aşağıdaki sorulara yanıt aranmıştır:

1. Kaynaştırma uygulamalarının yürütüldüğü sınıflarda çalışan okul öncesi öğretmenlerinin,

a. ÖG ya da RG çocukla etkileşim kurma düzeyleri nasıldır?

b. ÖG ya da RG çocuğa yönelttikleri olumlu davranışlarının (akademik ve sosyal davranışları onaylama davranışları ve öğrenme firsatı sunma davranışları) düzeyi nasıldır?

c. ÖG ya da RG çocuğa yönelttikleri olumsuz davranışlarının (onaylamama davranışları) düzeyi nasildir?

2. Kaynaştırma uygulamalarının yürütüldüğü okul öncesi sınıflara devam eden ÖG ya da RG çocukların,

a. akranlarıyla etkileşim kurma düzeyi nasıldır?

b. akranlarıyla ve ögrretmenleriyle olumlu etkileşimlerinin (uygun etkileşim başlatma ve etkileşime uygun tepki verme davranışları) düzeyi nasıldır?

c. akranlarıyla ve öğretmenleriyle olumsuz etkileşimlerinin (uygun olmayan etkileşim başlatma ve etkileşime uygun olmayan tepki verme davranışları) düzeyi nasıldır?

d. problem davranışlarının düzeyi nasıldır?

e. görev davranışlarının düzeyi nasıldır?

\section{Yöntem}

Okul öncesi kaynaştırma sınıflarındaki öğretmen ve ÖG ile RG çocukların sınıf içi davranışlarının incelenmesinin amaçlandığı bu çalışma betimsel bir araştırmadır. Bu bölümde çalışma grubu, veri toplama araçları, veri toplama süreci ve verilerin analizine ilişkin bilgilere yer verilmiştir.

\section{Çalışma Grubu}

Bu araştırmanın çalıșma grubunu Ankara'da bağımsız bir anaokulunda çalışan ve sınıfında ÖG ya da RG çocuk bulunan 17 okul öncesi öğretmeni ve sınıflarındaki ÖG çocuklar ile öğretmenler tarafından hem gelişimlerinin hem de davranışlarının akranlarından farklı olduğu belirtilen, dolayısıyla özel gereksinimli olma riski olduğu kabul edilen (RG) çocuklar oluşturmuştur. Öğretmenlerin tamamı üniversitelerin dört y1llık Okul Öncesi Öğretmenliği lisans programlarından mezun olmuşlardır ve tamamı kadındır. Öğretmenlerin yaş ve deneyimleri ile çocukları tanıma süresine ilişkin bilgiler Tablo 1'de verilmiştir.

Tablo 1

Araştırma Grubunda Yer Alan Öğretmenler ile ÖG ve RG Çocukların Özellikleri

\begin{tabular}{|c|c|c|c|c|}
\hline \multicolumn{5}{|c|}{ Öğretmen } \\
\hline Değișken & $\mathbf{N}$ & $\mathbf{X}$ & Ranj & SS \\
\hline Yaş & & $31.29 \mathrm{y} 1 \mathrm{l}$ & $21-52$ y1l & 7.28 \\
\hline Deneyim & 17 & $9 \mathrm{y} 1 \mathrm{l}$ & $0.5-30.5 \mathrm{y} 1 \mathrm{l}$ & 7.29 \\
\hline Çocuğu Tanıma Süresi & & 6 ay & $1-20$ ay & 4.95 \\
\hline \multicolumn{5}{|c|}{ ÖG çocuk } \\
\hline Değişken & $\mathbf{N}$ & $\mathbf{X}$ & Ranj & SS \\
\hline Yaş (ay) & 9 & 66 ay & $48-83$ ay & 10.74 \\
\hline \multicolumn{5}{|c|}{ RG çocuk } \\
\hline Yaş (ay) & 8 & 55 ay & $48-67$ ay & 7.46 \\
\hline
\end{tabular}


Tablo 1'e göre öğretmenlerin yaş ortalaması 31.29'dur. Öğretmenlik deneyimleri 6 ay ile 30 yıl arasında çocukları tanıma süreleri ise 1 ile 20 ay arasında değişmektedir. Araştırmanın çalışma grubundaki çocukların 10'u erkek, 7'si kızdır. ÖG çocukların yaş ortalamaları 66 ay, RG çocukların ise 55 aydır (Tablo 1). Çalışma grubundaki çocukların dokuzu hastaneler tarafından ÖG olarak tanılanmış ve Rehberlik Araştırma Merkezleri (RAM) tarafından özel eğitim hizmetleri için uygunluğuna karar verilmiş çocuklardır. Bu çocukların beşi zihinsel yetersizlik, ikisi otizm, biri görme yetersizliği ve biri de işitme yetersizliği tanısı almışlardır. Diğer sekiz çocuk ise öğretmenlerinin görüşlerine göre "ÖG tanısı alma riski olan" $R G$ çocuklardır. RG çocuklar, anne babalarının tanı almasını istemediği, bu nedenle de RAM'lar ya da hastanelere yönlendirilmemiş ancak gelişimsel ve davranışsal açıdan akranlarından ciddi derecede farklılıklar gösteren çocuklardır. Öğretmen görüşlerine göre bu çocuklar, problem davranışları ya da sınıf içi performansları nedeniyle ÖG tanısı alma olasılığı yüksek olan çocuklardır (Heward, 2013). Öğretmenler, çocuk gelişimi konusunda bilgili olmaları, aynı yaş grubundan çok sayıda çocuğu gözlemleme firsatları olması nedeniyle çocukların yeterlilikleri ile yetersizlikleri konusunda nesnel olarak karar verebilecek güvenilir ve önemli kaynaklar olarak kabul edilmektedirler (McDermott, 1993). Çocukların tanı almaları hastanelerde formal süreçlerle gerçekleştirilmesine karşın hafif derecede yetersizlikleri olan çocuklar için tanıya yönlendirme, özel eğitim hizmetleri için uygunluğuna karar verildiğinde amaç seçme ve program hazırlama, öğretimin hızını ayarlama gibi önemli kararlar, öğretmenlerin sınıf içi değerlendirmeleri ve aldıkları kararlara göre gerçekleştirilmektedir (Cotton, 1988). Sinıflarda öğretmenler ÖG olan ve olmayan çocukların değerlendirmesinden ve gelişiminden sorumlu birincil kişilerdir, çocukların performansını belirlemede güçlü değerlendiricilerdir, çocukların performans düzeylerini doğru şekilde değerlendirebilmekte ve değerlendirme sonuçlarına göre öğretimi yönlendirmektedirler (Anderson, 2007; Teach For America, 2011). Sonuç olarak bu çalışmada yer alan çocukların dokuzu tanı almış, sekizi ise öğretmenleri tarafindan ÖG tanısı alma ihtimali olan olduğu ifade edilen RG çocuklardan oluşmuştur. Öğretmen görüşlerine göre RG çocukların 6'sının duygusal ve davranışsal bozukluk, 2'sinin ise dil ve konuşma bozukluğu tanı alma riski olduğu görülmüş̧ür.

\section{Veri Toplama Araçları}

$\mathrm{Bu}$ araştırmada veri toplamak amaciyla Öğretmen ve Öğrenci Bilgi Formu ile öğretmen ve çocuk davranışlarını değerlendirmek amacıyla geliştirilen gözlem formları kullanılmıştır.

Öğretmen ve Öğrenci Bilgi Formu. Bu form, çalışma grubunda yer alan öğretmenlerin yaşları, deneyimleri, ÖG ya da RG çocuğu tanıma süresi gibi bilgiler ile sınıflarındaki ÖG ya da RG çocukların yaşları ve tanıları gibi bilgileri elde etmek amacıyla başka bir projede veri toplamak amacıyla geliştirilmiştir (Sucuoğlu ve diğ., 2015).

Öğretmen Davranışları Gözlem Formu (ÖDGF). Gözlem formu, öğretmenlerin ÖG ya da RG çocuğa yönelik etkileşim davranışları ile olumlu ve olumsuz davranışları belirlemek amacıyla geliştirilmiştir. Formun geliştirilmesinde daha önce bir projede veri toplamak amacıyla geliştirilen öğretmen gözlem formları (Sucuoğlu ve diğ., 2015) temel alınmıştır. Bu form öğretmenlerin serbest zaman etkinlikleri (SZE) ve masa baş1 etkinliklerinde (MBE) çocukla etkileşimlerinin (zamanı/süresi) ve çocuğa yönelttikleri olumlu ve olumsuz davranışların (sıklıklarının) belirlenmesi amacıyla kullanılmışır.

Formun geliştirilme sürecinde öncelikle alanyazında kaynaştırma uygulamaları yürütülen okul öncesi sınıflarda gözlem yapmak için geliştirilmiş olan formlar incelenmiştir. İnceleme sonucunda, öğretmenlerin ÖG ya da RG çocukla etkileşim kurma, çocuğun akademik ve sosyal davranışları için yönelttikleri onaylama davranışları ile öğrenme firsatı sunma davranışları ve çocuğa yönelttikleri onaylamama davranışlarının gözlem formlarında sıklıkla yer aldığı belirlenmiştir (Carta, Greenwood ve Atwater, 1985; Hundert, 2007; Malmskog ve McDonnell, 1999; Martin ve diğ., 2010; Schepis, Reid, Ownbey ve Parsons, 2001; Sutherland, Conroy, Vo, Abrams ve Ogston, 2012; Tsao, Odom ve Brown, 2001). İlgili alanyazın çerçevesinde belirlenen öğretmen davranışlarının objektif tanımları yapılmış, davranışların işlevsel tanımları ilgili davranışın karşısına yazılmıştır. Öğretmen davranışlarının işlevsel tanımları aşağıda verilmiştir. 
VE RISK GRUBU ÇOCUKLARIN SINIF İÇİ DAVRANIŞLARININ İNCELENMESİ

Öğretmenlerin etkileşim kurma davranışları iki şekilde kodlanmıştır: bireysel olarak ÖG ya da RG çocukla etkileşim kurma ve grup içinde çocukla etkileşim kurma. Bireysel olarak çocukla etkileşim kurma, öğretmenin çocuğun en fazla üç metre uzağında durarak çocuğa yönelik sözel veya sözel olmayan davranışta bulunmasıdır (örn. yönerge verir, yeniden yönlendirme yapar, yardım eder, materyal önerir, eliyle işaret eder vb.). Grup içinde çocukla etkileşim kurma ise öğretmenin çocuğun da içinde bulunduğu iki ya da daha fazla çocuğun en fazla üç metre uzağında durarak çocuklara yönelik sözel veya sözel olmayan davranışta bulunmasıdır (örn. yönerge verir, yeniden yönlendirme yapar, yardım eder, materyal önerir, eliyle işaret eder vb.).

Onaylama davranışları da, sosyal davranışları onaylama davranışları ve akademik davranışları onaylama davranışları olarak iki grupta kodlanmıştır. Sosyal davranışları onaylama davranışları, öğretmenin çocuğun paylaşma, yardımlaşma, selamlaşma vb. sosyal davranışlarını onayladığına ilişkin sözel (aferin, çok güzel, süper, bravo vb.) ya da sözel olmayan davranışlarıdır (çak, başparmak havada, eliyle süper işareti yapma vb.). Akademik davranışları onaylama davranışları ise öğretmenin çocuğun yazma, okuma, boyama, soru sorma, dinleme vb. akademik davranışları onaylamasına ilişkin sözel (aferin, çok güzel, süper, bravo vb.) veya sözel olmayan davranışları (çak, başparmak havada, eliyle süper işareti yapma vb.) olarak tanımlanmıştır.

Onaylamama davranışları, öğretmenin çocuğun davranışlarını onaylamadığına ilişkin "olmadı, doğru değil, beğenmedim, kaç kere söyledim vb." gibi sözel veya" parmak sallama, başını sallama vb." gibi sözel olmayan davranışları olarak belirlenmiştir.

Bir ögrenme firsatı sunma ise öğretmenin çocuğa bir soru sorması veya yönerge vermesi, çocuğun doğru tepkisini ödüllendirmesi, yanlış tepki ya da tepkinin olmaması durumunda ipucu sunması ve ortaya çıkan doğru tepkiyi ödüllendirmesi olarak gözlenebilir ve ölçülebilir şekilde ifade edilmiştir.

Formlarda yer alan etkileşim kurma davranışları için $15 \mathrm{sn}$. parçalı aralık kaydı ile onaylama-onaylamama davranışları ve öğrenme firsatı sunma davranışları için ise sıklık kaydı ile veri toplanmasına karar verilmiştir (Alberto ve Troutman, 2010). Parçalı aralık kaydı, davranışların başlangıcı ve bitişinin belirlenmesinin zor olduğu ya da çok sık çıktığı için sayılmasının zor olduğu durumlarda kullanılmaktadır (Kahng, Ingvarsson, Quigg, Seckinger ve Teichman, 2011). Yöntemin en büyük avantajı, davranışın sıklığı ve süresine ilişkin kestirimde bulunmaya imkân vermesi ve müdahalenin etkilerine ilişkin davranışlardaki değişiklikleri belirlemede oldukça hassas bir ölçüm yapabilmesidir (Harrop ve Daniels, 1986). Gözlem formunun kullanışlılığının belirlenebilmesi için bağımsız iki anaokulunda çalışan ve sınıfında ÖG çocuk bulunan üç okul öncesi öğretmeninin sınıfında yarım saat SZE ve yarım saat MBE olmak üzere toplam birer saat video kaydı yapılmıştır. Araştırmacı formları kullanarak video kayıtları ile gözlemler gerçekleştirmiş, formlar okul öncesi ögretmenliği ve özel eğitim alanlarında uzman olan beş kişiye verilerek formlar için kapsam geçerliliği çalışması yapılmıştır. Uzmanlardan, araştırmanın amacına göre formlarda yer alan davranışların tanımlarının uygun olup olmadığı ve davranışların kapsamının yeterli olup olmadığına ilişkin görüşleri istenmiştir. Uzmanların geribildirimlerine göre davranış tanımlarında düzenlemeler yapılmıştır. Örneğin davranışlar için verilen örnekler artırılmıştır (örn. sözel davranışlar için süper, harika, aferin vb.). Uzman görüşlerine göre düzenlendikten sonra formlar son haline getirilmiştir.

Çocuk Davranışları Gözlem Formu (ÇDGF). ÖG ya da RG çocukların akranlarıyla ve öğretmenle etkileşim kurmaları, akranlarla ve öğretmenle uygun şekilde etkileşim başlatma ve etkileşime tepki verme davranışları, uygun olmayan şekilde etkileşim başlatma ve etkileşime tepki verme davranışları, problem davranışları ile görev davranışlarının belirlenebilmesi için ÖDGF'ye benzer şekilde ÇDGF geliştirilmiştir. Öncelikle alanyazında okul öncesinde kaynaştırma uygulamalarının yürütüldüğü sınıflara devam eden ÖG çocukların davranışlarını incelemeye yönelik araştırmalar gözden geçirilmiştir. Bu araştırmalarda (Carta ve diğ., 1985; Hundert, 2007; Malmskog ve McDonnell, 1999; Martin ve diğ., 2010) temel alınan ÖG çocukların akranlarıyla ve öğretmenleriyle etkileşim kurma davranışları, uygun şekilde ve uygun olmayan şekilde etkileşim başlatma ve tepki verme davranışları, problem davranışları ve görev davranışlarına ÇDGF'de yer verilmiştir. 
Gözlem formlarında yer alan davranışlar objektif şekilde tanımlanmış ve davranışların işlevsel açıklamaları formlara eklenmiş̧ir. Çocuk davranışlarına iliş̧in işlevsel tanımlar aşağıda sunulmuştur:

Akran ile etkileşim kurma, diğer bir veya birden fazla akranından en fazla üç metre uzakta durarak/oturarak bu akranla etkileşime girme (örn. akranla konuşur, akrana dokunur, bir şey gösterir, bakar, seslenir, gülümser; akranı konuşuyorsa onu/onları dinler, bakar, sıra alır ve verir vb.), bir görev üzerinde çalışılıyorsa akrana yönelik etkileşim davranışı sergileyerek görevi yerine getirme (örn. akranla aynı kitaba bakar, aynı oyuncağı eller, akrana dokunur, boya kalemini/etkinlik materyalini paylaşır, akranına soru sorar, akranına kendi kitabından doğru cevabı gösterir vb.) olarak tanımlanmıştır

Etkileşim başlatma davranışları, etkileşimi uygun şekilde başlatma ve etkileşimi uygun olmayan şekilde başlatma olarak kodlanmıştır. Etkileşimi uygun şekilde başlatma, akranın ya da öğretmenin yanına giderek en fazla bir metre uzaklıkta durma/oturma ve etkileşim başlatmak için uygun motor davranışta bulunma veya ses ya da sözle etkileşim kurma (örn. arkadaşının sırtına/koluna vb. hafif̧̧e dokunur, arkadaşının adını söyler, bir şey rica eder, bakar mısın, gelir misin veya bak, gel vb.), arkadaşının tepkisini bekleme, etkileşimi uygun olmayan şekilde başlatma ise akranından ya da öğretmeninden bir şey istemek, bir şey söylemek için uygun olmayan sözel ya da motor davranışta bulunmadır (örn. bir şey söylemek ya da istemek için arkadaşının tişörtünü çeker, arkadaşını iter vb.).

Etkileşime tepki verme davranışları da benzer şekilde etkileşime uygun şekilde tepki verme ve etkileşime uygun olmayan şekilde tepki verme olarak gruplanmıștır. Etkileşime uygun şekilde tepki verme, akranı ya da öğretmeni yanına gelerek, sözel ya da motor bir davranışla etkileşim başlattığında, en fazla bir metre uzaklıkta durma/oturma ve bireyin etkileşim başlatmasına uygun tepki verme (örn. başını evet/hayır anlamında sallar, sorulan soruya uygun şekilde cevap verir, sohbeti sürdürür), etkileşime uygun olmayan şekilde tepki verme ise akranı ya da öğretmeni yanına gelerek etkileşim başlattığında uygun olmayan şekilde sözel ya da motor davranış sergileme (örn. kendisinden bir şey isteyen ya da bir şey soran arkadaşını iter, arkadaşına sırtını döner vb.) ya da tepki vermeme olarak tanımlanmıştır.

Problem davranışlar vurma, bağırma, ağlama gibi sınıf düzenini bozan sözel veya sözel olmayan problem davranışları, görev davranışları ise MBE sırasında öğretmenin verdiği göreve ilişkin materyal ve göreve çocuk dikkatini yöneltme, uygun motor davranışta bulunma (örn. yazar, oyun kurallarına uyar vb.), (uygun olduğunda/gerekli olduğunda) uygun şekilde yardım isteme (örn. parmak kaldırır vb.) ve uygun sözel ve sözel olmayan davranışları sergileme (örn. dans eder, şarkı söyler, makasla keser vb.) olarak tanımlanmıştır.

Formlarda yer alan etkileşim kurma davranışları ile problem davranışlar $15 \mathrm{sn}$. parçalı aralık kaydı, görev davranışları ise bütüncül aralık kaydı ile değerlendirilmiş̧ir (Alberto ve Troutman, 2010). Uygun olan ve olmayan şekilde etkileşim başlatma ve etkileşime tepki verme davranışları ise sıklık kaydı tutularak kaydedilmiştir. Gözlem formunun kullanışl1lığının belirlenebilmesi için ÖDGF'nin kullanışl1lı̆̆ını değerlendirmek üzere bağımsız iki anaokulunda çalışan ve çalışmanın denekleri arasında yer almayan üç okul öncesi öğretmeninin sınıfında çekilen aynı videolar kullanılmış, formlar kullanılarak video kayıtları ile gözlemler gerçekleştirilmiştir. Daha sonra formlar okul öncesi öğretmenliği ve özel eğitim alanlarında çalışan beş uzmana verilerek kapsam geçerliliği incelenmiş; uzman görüşlerine göre davranışların işlevsel açıklamalarına sözel ve sözel olmayan davranışlar için örnekler eklenmiş, böylece formlar son haline getirilmiştir.

\section{Verilerin Toplanması ve Analizi}

Araştırmada veri toplanmadan önce öncelikle Milli Eğitim Bakanlığı’ndan (MEB) gerekli yasal izinler alınmıştır. Ardından araştırmaya katılmaya gönüllü olduklarını belirten bir bağımsız anaokulunun müdüründen, okulda çalışan öğretmenler ve sınıflarındaki çocukların velilerinden izin alma süreci gerçekleştirilmiştir. $\mathrm{Bu}$ süreçte öğretmenlerle bir oturum gerçekleştirilerek sözlü olarak araştırmanın amacı açıklanmıştır. Çalışma grubunda yer alacak çocukların belirlenmesinde çocukların hastanelerden aldıkları tanılar istenmiş ya da öğretmenlerin görüşlerine göre RG olmaları beklenmiştir. Öğretmenlere RG çocuklar “ÖG tanısı almamış ancak 
VE RISSK GRUBU ÇOCUKLARIN SINIF İÇİ DAVRANIŞLARININ İNCELENMESİ

sınıfta sergilediği problem davranışlar ve/veya öğrenme güçlüğü nedeniyle ileride ÖG tanısı alma olasılığı olan çocuk" (Heward, 2013) olarak anlatılmış, öğretmenlerden sınıflarında bu özellikleri gösteren çocuk var ise onu RG olarak aday göstermeleri istenmiştir. Bu amaçla araştırmada bilgi toplamak amacıyla kullanılan Öğretmen ve Öğrenci Bilgi Formu'nda öğretmenlerin tanılı olmayan ancak risk grubunda yer aldıklarını düşündükleri çocukların davranışlarını ayrıntılı olarak belirtmeleri istenmiştir. Buna göre her sınıftan ÖG ya da RG olan birer çocuk belirlenmiştir. Sonrasında tüm velilere araştırmanın amacının yazılı olduğu bir dilekçe verilerek çalışmaya katılmak isteyip istemediklerine ilişkin dilekçeyi imzalamaları istenmiştir.

Gerekli izinler alındıktan sonra her bir öğretmenin sınıfında yarım saat SZE ve yarım saat MBE’de olmak üzere toplam birer saatlik video çekimleri gerçekleştirilmiştir. Video çekimleri sırasında Ankara Üniversitesi Eğitim Bilimleri Fakültesi Zihin Engelliler Öğretmenliği Bölümü üçüncü sınıf öğrencisi iki kişi sınıfta çekim için hazır bulunmuştur. Kameralar öğretmenin ve ÖG ya da RG çocuğun etkileşim kurduğu kişileri görebilecek şekilde yerleştirilmiştir. Öğrenciler çocukların dikkatini çekmeyecek şekilde sınıfın uygun köşelerinde durmuş, kameralardan biri ile ÖG ya da RG çocuğun diğeri ile de öğretmenin davranışlarını kaydetmişlerdir. On yedi öğretmen için toplam 17 saat çekim yapılmış ve çekimler iki hafta içerisinde tamamlanmıştır.

Gözlem yoluyla toplanan verilerin bazıları gruplanarak analiz edilmiştir. Öğretmenlerin davranışları üç grupta toplanmış, analizler üç grup davranış üzerinden gerçekleştirilmiştir. Üç grup öğretmen davranışı aşağıda sıralanmıştır:

a) Çocuk ile etkileşim kurma: ÖG ya da RG çocuk ile bireysel olarak ve grup içerisinde etkileşim kurma yüzdelerinin (parçalı aralık kaydı) toplamı,

b) Olumlu davranışlar: öğretmenlerin ÖG ya da RG çocuğa yönelttikleri sosyal ve akademik davranışları onaylama ve öğrenme firsatı sunma davranışlarının sıklıklarının toplamı,

c) Olumsuz davranışlar: öğretmenlerin onaylamama davranışları.

Benzer şekilde ÖG ve RG çocukların davranışları beş grup davranış olarak gruplanmış ve analizler beş grup davranış üzerinden yapılmıştır. Beş grup çocuk davranışı aşağıda sunulmuştur:

a) Akranlarla etkileşim kurma: ÖG ya da RG çocukların tek bir akran ve grup içinde akranlarıyla etkileşimlerinin yüzdelerinin (parçalı aralık kaydı) toplamı,

b) Akranlarla ve öğretmenlerle olumlu etkileşim: ÖG ya da RG çocukların akranları ve öğretmenlerine yönelttikleri uygun şekilde etkileşim başlatma ve etkileşime tepki verme davranışlarının sıklıklarının toplamı,

c) Akranlarla ve öğretmenlerle olumsuz etkileşim: ÖG ya da RG çocukların akranlar ve öğretmenlerine yönelttikleri uygun olmayan etkileşim başlatma ve etkileşime tepki verme davranışlarının sıklıklarının toplamı,

d) Problem davranışlar ve

e) Görev davranışları.

Çocuk ve öğretmen davranışlarına ilişkin yüzdeler ve sıklıklar SPSS 22 paket programına girilmiş ve veriler analiz edilirken yüzdeler ve sıklıklara ilişkin ortalama ve standart sapmaları hesaplanmıştır. Çocuk davranışlarında a, b, c, d ve e'de yer alan davranışlar için ÖG ve RG çocukların sıra ortalamaları arasındaki farklar Mann Whitney U testi kullanılarak karşılaştırılmış sonuçlar ilgili başlıklar altında ayrı ayrı verilmiştir.

Toplanan gözlem verilerinin doğruluğuna ilişkin gözlemci güvenirliği ve gözlemciler arası güvenirlik çalışmaları (Wolery, 2011) gerçekleştirilmiştir. Bu amaçla öncelikle araştırmacı gözlem formlarını kullanarak doğru veri toplayıp toplamadığını belirlemek üzere çalışma grubunda yer almayan üç öğretmenin sınıfında çekilmiş yarım saat SZE ve yarım saat MBE'ye ilişkin videoları iki hafta arayla izleyerek gözlemci güvenirliği / gözlemler arası güvenirlik çalışmasını gerçekleştirmiştir. Gözlemler arası güvenirlik katsayıları parçalı aralık 
kaydı ve bütüncül aralık kaydı ile gerçekleştirilen gözlemler için "Görüş birliği olan aralık sayısı / Görüş birliği + Görüş ayrılığı olan aralık sayısı x 100" formülü” (Tekin-İftar, 2012) ile sıklık kaydı yapılan davranışlar için ise "Küçük sayı / Büyük sayı x 100” formülü (Casey ve McWilliam, 2008) ile hesaplanmıştır. Gözlemci güvenirliği katsayılarının öğretmenlerin onaylama-onaylamama davranışları ve öğrenme firsatı sunma için \%100, etkileşim davranışları için \%94; çocukların etkileşim başlatma ve etkileşime tepki verme davranışları için \%92, etkileşim kurma, problem davranışlar ve görev davranışları için ise sırasıyla $\% 94, \% 100$ ve $\% 95$ olduğu belirlenmiş̧tir. Bu sonuçlara göre $\% 80$ olan gözlemciler arası güvenirlik ölçütü karşılanmıştır (Tekin-İftar, 2012). Böylece araştırmacının gözlemleri doğru olarak gerçekleştiğine karar verilerek gözlemciler arası güvenirlik çalışmasına geçilmiştir.

Ankara Üniversitesi Eğitim Bilimleri Fakültesi Zihin Engelliler Öğretmenliği Bölümü üçüncü sınıfa devam eden ve Uygulamalı Davranış Analizi dersini başarıyla tamamlamış altı gönüllü̈ lisans öğrencisi bağımsız gözlemci olarak yetiştirilmiştir. Gözlemciler arası güvenirliğin veri toplanan oturumların en az \%20'sinde gerçekleştirilmesi gerektiği belirtilmektedir (Tekin-İftar ve Kırcaali-İftar, 2004). Bu araştırmada toplanan toplam 17 saatlik video çekimlerinin \%30’u için (5 saat) gözlemciler arası güvenirlik yüzdeleri hesaplanmıştır. Gözlemciler arası güvenirlik katsayıları, gözlemci güvenirliği katsayıları için kullanılan formüller ile hesaplanmıştır. Öğretmen ve çocuk davranışlarına ilişkin gözlemci güvenirliklerinin ortalaması Tablo 2'de verilmiştir. Tablo 2 incelendiğinde öğretmen ve çocuk davranışları için MBE ve SZE'de güvenirliklerin ranjlarının \%78-100, ortalamalarının ise \%84-96 arasında değiştiği görülmektedir.

Tablo 2

Çalışma Grubunda Yer Alan Öğretmen ve ÖG ve RG Çocuklar için Toplanan Verilerin Gözlemciler Arası Güvenirlik Katsayılarının Ortalaması

\begin{tabular}{|c|c|c|}
\hline \multicolumn{3}{|c|}{ Öğretmen Davranışları için Gözlemciler Arası Güvenirlik Katsayılarının Ortalaması } \\
\hline Gözlenen Davranış & MBE & SZE \\
\hline Etkileşim Kurma & \%94 (ranj: \%86-100) & $\% 92$ (ranj: \%80-100) \\
\hline Onaylama-Onaylamama & $\% 94$ (ranj: \%86-100) & $\% 96$ (ranj: \%90-100) \\
\hline Öğrenme Firsatı Sunma & $\% 86$ (ranj: \%82-100) & $\% 90$ (ranj: \%80-100) \\
\hline \multicolumn{3}{|c|}{ ÖG ve RG Çocuk Davranışları için Gözlemciler Arası Güvenirlik Katsayılarının Ortalaması } \\
\hline Gözlenen Davranış & MBE & SZE \\
\hline Etkileşim Kurma & $\% 92$ (ranj: \%88-100) & $\% 90$ (ranj: \%88-100) \\
\hline Etkileşim Başlatma & $\% 86$ (ranj: \%78-100) & $\% 84$ (ranj: \%80-100) \\
\hline Etkileşime Tepki Verme & $\% 84$ (ranj: \%78-100) & $\% 88$ (ranj: \%82-100) \\
\hline Problem Davranış & $\% 92$ (ranj: \%88-100) & $\% 94$ (ranj: \%88-100) \\
\hline Görev Davranışları & $\% 90$ (ranj: \%80-100) & \\
\hline
\end{tabular}

MBE: Masa başı etkinlik, SZE: Serbest zaman etkinliği

\section{Bulgular}

Okul öncesi kaynaştırma sınıflarındaki öğretmen ve ÖG ve RG çocukların sınıf içi davranışlarının incelendiği çalışmanın bu bölümünde araştırma soruları doğrultusunda yürütülen istatistiksel analizlerin sonuçları verilmiştir.

\section{Öğretmen Davranışlarına İlişskin Bulgular}

1) Okul öncesi öğretmenlerin ÖG ya da RG çocukla etkileşim kurma düzeyi. Sınıfında ÖG ya da RG çocuk bulunan 17 okul öncesi öğretmeninin sınıflarındaki ÖG ve RG çocukla etkileşim kurma düzeylerinin yüzdeleri ve standart sapmaları MBE ve SZE için ayrı ayrı hesaplanarak Tablo 3'te verilmiştir. Tabloya göre ögretmenler çocuklarla, bireysel olarak ya da grup içinde 30 dakikalık MBE'nin yaklaşı \% 16.40 'ında SZE'nin ise \%14.26'sında etkileşim kurmuşlardır. 
2) Okul öncesi öğretmenlerin ÖG ya da RG çocuğa yönelttikleri olumlu davranışlar. Okul öncesi öğretmenlerinin ÖG ve RG çocuğa yönelttikleri olumlu davranışlarının (sosyal ve akademik davranışları onaylama ve öğrenme firsatı sunma), sıklıklarının ortalaması ve standart sapması hesaplanarak Tablo 3'te verilmiştir. Tablo incelendiğinde öğretmenlerin MBE'de olumlu davranışları ortalama yaklaşık 21 kez, SZE'de ise ortalama $18 \mathrm{kez} \mathrm{çocuğa} \mathrm{yönelik} \mathrm{olumlu} \mathrm{davranış} \mathrm{sergiledikleri} \mathrm{görülmüştür.}$

3) Okul öncesi öğretmenlerin ÖG ya da RG çocuğa yönelttikleri olumsuz davranışlar. Öğretmenlerin ÖG ve RG çocuğa yönelttikleri olumsuz davranışlarının sıklıklarının ortalaması ve standart sapması hesaplanarak Tablo 3'te verilmiştir. Tabloya göre öğretmenlerin çocuklara yönelttikleri olumsuz davranışların hem MBE (1.70) hem de SZE’de (1.29) oldukça az olduğu görülmektedir.

Tablo 3

Sınıfında ÖG ve RG Çocuk Bulunan Okul Öncesi Öğretmenlerinin Davranışlarına İlişkin Yüzdeler ve Sıklıkların Ortalamalarl ve Standart Sapmalarl

\begin{tabular}{|c|c|c|c|c|}
\hline \multirow[t]{2}{*}{ Öğretmen Davranışları } & \multicolumn{2}{|c|}{$\mathrm{MBE}$} & \multicolumn{2}{|c|}{ SZE } \\
\hline & $\mathbf{X}$ & SS & $\mathbf{X}$ & SS \\
\hline ÖG ve RG çocuk ile etkileşim kurma* & 16.40 & 11.22 & 14.26 & 14.00 \\
\hline Olumlu davranışlar $* *$ & 20.88 & 17.42 & 17.58 & 18.90 \\
\hline Olumsuz davranışlar** & 1.70 & 2.11 & 1.29 & 2.05 \\
\hline
\end{tabular}

*Davranışların sergilendiği gözlem aralıklarının yüzdesi, ** Davranışların sıklığı, MBE: Masa başı etkinlik, SZE: Serbest zaman etkinliği

\section{Çocuk Davranışlarına İliş̧kin Bulgular}

1) ÖG ya da RG çocuğun akranlarıyla etkileşim kurma düzeyi. Kaynaştırma uygulamalarının yürütüldüğü sınıflara devam eden 17 ÖG ya da RG çocuğun akranlarıyla etkileşim kurma düzeyleri için tek bir akranla ve grup içinde akranlarla etkileşim yüzdelerinin toplamı ve standart sapmaları MBE ve SZE için ayrı ayrı hesaplanarak Tablo 4'te verilmiştir. Tabloya göre çocuklar akranlarıla 30 dakikalık MBE süresinin yaklaşık \%8.46'sında; SZE'nin ise \%20.31'inde akranlarıyla etkileşim kurmuşlardır. Bu bulgu, ÖG ya da RG çocukların SZE'de akranlarıyla daha fazla etkileşim kurduklarını göstermektedir.

Çalışma grubunda yer alan ÖG çocuklar (SZE için Medyan $[M]=9.33$, MBE için $M=10.00$ ) ile RG çocukların (SZE için $M=8.63$, MBE için $M=7.88$ ) etkileşim kurma düzeyleri karşılaştırıldığında iki grubun sıra ortalamaları arasındaki farkların hem SZE $(U=33.00)$ hem MBE için $(U=27.00)$ anlamlı olmadığı belirlenmiştir $(p>.05)$.

2) Okul öncesi sınıflarda ÖG ya da RG çocukların olumlu etkileşimleri. ÖG ya da RG çocukların akranlara ve öğretmenlere yönelik uygun etkileşim başlatma ve etkileşime uygun tepki verme davranışlarının sıklığı toplanmış, ortalamaları ve standart sapmaları hesaplanarak Tablo 4'te verilmiştir. MBE'de çocuklar ortalama $18 \mathrm{kez}$ olumlu etkileşim kurmuşlardır. SZE'de ise bu ortalama 25'tir. Bu sonuçlara göre çocukların SZE'de olumlu etkileşimleri MBE'ye göre biraz daha fazladır.

ÖG çocuklar (SZE için $M=6.33$, MBE için $M=7.50$ ) ile RG çocuklar (SZE için $M=7.87$, MBE için $M=10.69)$ olumlu etkileşimler açısından SZE $(U=22.00)$ ve MBE'de $(U=22.50)$ anlamlı şekilde farklılaşmamışlardır $(p>.05)$.

3) Okul öncesi sınıflarda ÖG ya da RG çocukların olumsuz etkileşimleri. ÖG ya da RG çocukların akranlarıyla ve öğretmenleriyle olumsuz etkileşimlerinin belirlenebilmesi için akran ve öğretmene yönelttikleri uygun olmayan şekilde etkileşim başlatma ve etkileşime uygun olmayan şekilde tepki verme davranışlarının sıklığı toplanmış, standart sapmaları hesaplanmış ve bulgular Tablo 4'te verilmiştir. Çocuklar MBE'de ortalama $7 \mathrm{kez}$, SZE'de ise yaklaşık 9 kez olumsuz etkileşim sergilemişlerdir. Her iki etkinlik için de olumsuz etkileşimlerin ortalamaları birbirine çok yakındır. 
Olumlu etkileşim için olduğu gibi olumsuz etkileşimler açısından da ÖG çocuklar (SZE için $M=6.61$, MBE için $M=6.56$ ) ile RG çocuklar (SZE için $M=6.69$, MBE için $M=7.75)$, SZE $(U=24.50)$ ve MBE'de $(U=24.00)$ anlamlı şekilde farklılaşmamışlardır ( $p>.05)$.

4) Okul öncesi sınıflarda ÖG ya da RG çocukların problem davranışları. ÖG ya da RG çocukların MBE ve SZE'de sergiledikleri problem davranışların yüzdeleri (parçalı aralık kaydı sonuçlarına göre) ile standart sapmaları hesaplanmış ve Tablo 4'te verilmiştir. Tablo incelendiğinde çocuklar MBE'nin ortalama \%32.37'sinde problem davranış sergilemişler, SZE'nin ise yaklaşık \%29.48'ini problem davranış sergileyerek geçirmişlerdir.

İki grup çocuk karşılaştırıldığında ÖG çocukların (SZE için $M=6.78$, MBE için $M=7.28$ ) RG çocuklara göre (SZE için $M=11.50$, MBE için $M=10.94)$, SZE ( $U=16.00)$ ve MBE'de $(U=20.50)$ problem davranışlar açısından anlamlı şekilde farklılaşmadıkları belirlenmiştir $(p>.05)$.

5) Okul öncesi sınıflarda ÖG ya da RG çocukların görev davranışları. Araştırmanın son bulgusu, ÖG ya da RG çocukların MBE'nin yaklaşı olarak ne kadarında görev davranışlarını sergiledikleri ile ilgilidir. ÖG ya da RG çocukların bütüncül aralık kaydına göre görev davranışlarını sergileme yüzdeleri belirlenmiş, standart sapması hesaplanarak Tablo 4'te verilmiştir. Tablo incelendiğinde ortaya çıkan sonuç, çocukların MBE'nin yaklaşık \%44'ünde öğretmenin verdiği görev üzerinde çalışmış olduklarıdır.

MBE'de ÖG çocukların $(M=7.89)$ RG çocuklara göre $(M=10.50)$ görev davranışları açısından anlamlı şekilde farklılaşmadıkları belirlenmiştir $(U=26.00, p>.05)$.

Tablo 4

Kaynaştırma Uygulamalarının Yürütüldüğ̈̈ Okul Öncesi Sinfflarına Devam Eden ÖG ya da RG Çocukların Davranışlarına Illişkin Yüzdeler ve Siklıkların Ortalamaları ve Standart Sapmaları

\begin{tabular}{|c|c|c|c|c|}
\hline \multirow[b]{2}{*}{ Çocuk Davranışları } & \multicolumn{2}{|c|}{ MBE } & \multicolumn{2}{|c|}{ SZE } \\
\hline & $\mathrm{X}$ & SS & $\mathrm{X}$ & SS \\
\hline Akranlarla etkileşim kurma* & 8.46 & 7.55 & 20.31 & 15.38 \\
\hline Akranlarla ve öğretmenle olumlu etkileşimler** & 18.11 & 11.46 & 25.05 & 16.01 \\
\hline Akranlarla ve öğretmenle olumsuz etkileşimler** & 7.00 & 9.13 & 8.70 & 10.45 \\
\hline Problem davranışlar* & 32.37 & 29.48 & 18.36 & 21.04 \\
\hline Görev davranışları* & 44.02 & 19.41 & & \\
\hline
\end{tabular}

*davranışların sergilendiği gözlem aralıklarının yüzdesi, ** davranışların sıklığı, MBE: Masa başı etkinlik, SZE: Serbest zaman etkinliği

\section{Tartışma ve Sonuç}

Okul öncesi öğretmenlerinin ve sınıflarındaki ÖG ya da RG çocukların davranışlarının incelendiği bu çalışmada 17 sınıfta öğretmen ve çocuk davranışları video ile kaydedilmiştir. Video kayıtları MBE ve SZE'de yarımşar saat süreyle gerçekleştirilmiş, sonrasında öğretmen ve çocuk davranışları geliştirilen gözlem formları ile videolar üzerinden analiz edilmiştir. Araştırmanın bulgularına bakıldı̆̆ında öğretmenlerin ÖG ya da RG çocuklarla SZE ve MBE'de benzer oranda etkileşim kurdukları görülmüştür. Gözlem yapılan 30 dakika içinde çocuğa yönelik yaklaşık $20 \mathrm{kez}$ olumlu davranış sergilemişler, bir başka deyişle 1.5 dakikada bir çocuğu onaylamış ya da öğrenme firsatı sunmuşlardır. Öğretmenlerin ÖG ya da RG çocuğa yönelik olumsuz davranışları hemen hemen hiç yoktur. Öğretmenlerin olumsuz davranışlarının az olması, özellikle MBE'de ÖG ya da RG çocukların gözlem süresinin \%30'unda problem davranış sergilemelerine karşın öğretmenlerin bu davranışları görmezden geldiğine ve davranışlara tepki vermediklerine işaret ediyor olabilir. Benzer şekilde ÖG ya da RG çocukların MBE’nin yaklaşık yarısında (\%44) görev davranışları üzerinde çalışıyor olmaları da öğretmenlerin ÖG ya da RG çocuklar görev üzerinde çalışmadıklarında müdahale etmediklerini düşündürmüştür.

Çalışmanın bulguları toplu olarak ele alındığında öğretmenlerin, ÖG ya da RG çocuklarla, etkileşim ve iletişimin en fazla olabileceği düşünülen SZE'de, çocuklarla etkileşim kurma düzeyleri MBE’ye benzer 
VE RISK GRUBU ÇOCUKLARIN SINIF IÇİ DAVRANIŞLARININ INCELENMESI

bulunmuştur. ÖG ya da RG çocukların akranlarıyla etkileşim kurdukları yaklaşık süre SZE için 30 dakikada yaklaşık 6 dakikadır (gözlem yapılan sürenin yaklaşık \%20'si). Bu oran MBE için 30 dakikada yaklaşık 3 dakikadır (gözlem yapılan sürenin yaklaşık \%9'u). ÖG ya da RG çocuklar akranlarıyla ve öğretmenleriyle MBE ve SZE olmak üzere bir saatlik gözlem süresinde toplamda ortalama 59 kez etkileşim kurmuşlar (etkileşim başlatma ya da etkileşime tepki verme) diğer bir ifadeyle dakikada bir akranları ya da öğretmenleriyle etkileşim kurmuşlardır. ÖG ya da RG çocukların akranları ya da öğretmenleriyle etkileşimlerinin \%73'ü (43 kez) olumlu olmuştur. ÖG ya da RG çocukların problem davranış sergileme düzeyleri MBE için daha yüksek bulunurken, çocuklar MBE'nin yaklaşık 10 dakikasını (gözlem yapılan sürenin yaklaşık \%32'si) SZE'nin ise 5 dakikasını (gözlem yapılan sürenin yaklaşık \%18'i) problem davranış sergileyerek geçirmişlerdir. İlkokul sınıflarında gerçekleştirdiği çalışmasında Güner-Yıldız (2015), hafif derecede zihinsel yetersizliği olan çocukların gözlem süresinin \%58.58'inde görev üzerinde çalıştıkları, \%34.11'inde görev dışı davranışlarda bulundukları, $\%$ 7.31'inde ise problem davranışlar sergilediklerini belirlemiştir.

$\mathrm{Bu}$ araştırmanın bulguları aynı zamanda öğretmenlerin ÖG ya da RG çocukları akranlarıyla etkileşimlerinin artması için yeterince yönlendirmediklerini düşündürmektedir. Bunun yanı sıra çocukların bilişsel etkinliklerin \%32'sinde problem davranış sergilemeleri MBE'nin ÖG ya da RG çocukların özelliklerine göre uyarlanmamış olabileceğini akla getirmektedir. Çünkü alanyazında öğretim etkinliklerinin çocukların özelliklerine göre uyarlanması ile hem çocukların etkinliğe katılımlarının arttığı hem de problem davranışlarının azaldığı vurgulanmaktadır (Kern, Delaney, Clarke, Dunlap ve Childs, 2001). Bu nedenle daha sonra yapılacak çalışmalarda ÖG ya da RG çocukların bulunduğu sınıflarda yapılan uyarlama ve bireyselleştirme çalışmalarının çocuk davranışları ile birlikte ayrıntılı olarak incelenmesi gerektiği düşünülmektedir. Bu çalışmada öğretmenlerin ÖG ya da RG çocuklara yönelik olumlu davranışları sık (1.5 dakikada bir), olumsuz davranışları ise çok az bulunmuştur (en fazla 1-2 kez). ÖG ya da RG çocukların öğretmenleri ve akranlarıyla olumlu etkileşimlerinin sıklığının (bir saatlik gözlem süresinde toplamda ortalama $59 \mathrm{kez}$, başka bir deyişle dakikada bir) öğretmenlerin davranışlarıyla ilişkili olduğu söylenebilir. Bunun nedeni öğretmenin dikkatini ve ilgisini çocuğa yönlendirmesi, çocuk için ödül ve teşvik kullanması ile çocuğun sosyal davranışlarının da artmasından ileri geliyor olabilir (O’Leary ve O’Leary, 1972). İlkokul öğretmenleriyle yapılan bir çalışmada Sazak-Pınar ve Güner-Yıldız (2013), öğretmenlerin onaylama davranışlarını onaylamama davranışlarına oranla daha az kullandıklarını, sosyal onaylama/onaylamama davranışlarını akademik onaylama/onaylamama davranışlarından daha az kullandıklarını, normal gelişim gösteren çocukları ÖG çocuklara oranla daha fazla onayladıklarını belirlemişlerdir. Güner-Yıldız (2015) da ilkokul öğretmenleriyle yaptığı çalışmasında öğretmenlerin ÖG çocukları onaylama-onaylamama oranlarının çok düşük (gözlem süresinin \%0.13'ünde onaylama, \%0.27'sinde onaylamama davranışları) olduğunu ortaya koymuştur.

Bu araştırmada, öğretmen-çocuk çiftlerinin davranışlarının gözlenmesinin yanı sıra informal gözlem ve görüşmeler sırasında anekdot kayıtları da tutulmuştur. Bu kayıtlar, araştırmacının araştırma süresince tuttuğu öznel notlarını içermiştir. Anekdot kayıtları araştırmacıların araştırma sırasındaki deneyimleri, duyumları ve gözlemlerinin raporlanmasıdır (Tomal, 2010). Bilimsel veri toplama yöntemlerine dayalı olmadan toplanan, bu nedenle de kanıtları ya da güvenirliği sunulamayan anekdot kayıtları bu dezavantajlarına karşın bu çalışmada önemli bilgiler sunmuştur. Örneğin, MBE, materyalinin ve öğretim yönteminin önceden belirlendiği etkinliklerdir. SZE ise genellikle çocukların akranlarıyla oyun oynadıkları yapılandırılmamış etkinlikler olarak kabul edilir. Araştırmacının anekdot kayıtlarına göre öğretmenler serbest zamanları, çocukların serbest bırakıldığı, kendi kendilerine oynadıkları ve aralarında çıkan problemleri kendi kendilerine çözmelerinin beklendiği bir zaman aralığı olarak kabul etmektedirler. Örneğin, bir öğretmen "Ben serbest zamanda çocuklara hiç karışmıyorum, onların kendi kendilerine oynamalarını bekliyorum, ben de bu zaman aralığında yapmam gereken bazı işleri yapıyor, bazen form dolduruyor bazen de bir sonraki etkinliği planlıyorum." demiştir. Öğretmenlerin ÖG ya da RG çocukla yaklaşık etkileşim kurma süresinin SZE'de daha az olmasının bu bakış açısından etkilendiği düşünülebilir. 
Araştırma bulguları değerlendirilirken çalışmada öğretmenlerin ve çocukların etkileşim kurma davranışları ve problem davranışlar için parçalı aralık kaydı, çocukların görev davranışları için bütüncül aralık kaydı kullanılmış diğer davranışlar için sıklık kaydı gerçekleştirilmiştir. Yaklaşık kayıt teknikleri olan parçalı aralık kaydı ve bütüncül aralık kaydının davranışların süresine ilişkin doğru ve güvenilir bilgiler verdiği kabul edilmektedir (Alberto ve Troutman, 2010). Ancak, bu teknikler davranışların sıklığı, süresi ve davranıştaki küçük değişikliklerin değerlendirilmesinde kesin kayıt teknikleri göre daha yanıltıcı bilgiler verebilmektedir (Kahng ve diğ., 2011). Bu araştırmada birçok davranışın aynı anda kodlanması nedeniyle her davranışa ilişkin en iyi veriyi elde edebilmek için farklı kayıt teknikleri tercih edilmiştir.

Alanyazında öğretmen görüşlerine göre ÖG çocukların normal gelişim gösteren akranlarıyla problem davranışlarının karşılaştıııldı̆̆ çalışmalarda ÖG çocukların problem davranışlarının akranlarından fazla olduğu açıklanmaktadır (Aykır ve Çifci-Tekinarslan, 2012; Merrell ve Holland, 1997). Diğer taraftan öğretmenler de bu davranışların fazlalığı nedeniyle bu çocukları sınıflarında istememektedirler (Hanrahan, Goodman ve Rapagna, 1990). Oysa bu çalışmanın bulgularına göre, çalışma grubunun problem davranışları genel olarak azdır. İlkokul düzeyinde kaynaştırma uygulamalarının yürütüldüğü sınıflarda öğretmen ve çocuk davranışlarına ilişkin bir çalışmada da ÖG öğrencilerin problem davranışlarının az, görev davranışlarının da normal gelişim gösteren akranlarına benzer olduğu belirlenmiştir (Akalın, 2007). Zihinsel yetersizlikleri ve gelişimsel gerilikleri daha fazla olan çocukların problem davranış sergileme olasılıklarının daha fazla olduğu göz önüne alındığında (Lovell ve Reiss, 1993), bu bulgu ülkemizde hafif düzeyde yetersizliği olan dolayısıyla da hafif düzeyde problem davranış sergileyen çocukların okul öncesi kurumlara devam etmesinden (MEB, 2014) kaynaklanıyor olabilir.

$\mathrm{Bu}$ çalışmada öğretmenlerinin gelişimsel ve davranışsal açıdan akranlarından ciddi farklılıklar gösterdiğini belirttiği ve RG olduğu kabul edilen çocuklar da araştırmaya dâhil edilmiştir. Öğretmenlerin çocuk davranışlarına ilişkin nesnel karar verebilecek güvenilir kaynaklar olduğu kabul edilmiştir (McDermott, 1993). Çalışma grubunda yer alan ÖG çocuklar ile RG çocukların akranlarıyla etkileşim kurma, akranlar ve yetişkinlere yönelttikleri olumlu ve olumsuz davranışlar, problem davranışlar ve görev davranışları açısından birbirlerinden anlamlı şekilde farklılaşmamasının öğretmenlerin RG çocukları belirlemede güvenilir kaynaklar olduğu görüşünü desteklediği düşünülmüştür.

$\mathrm{Bu}$ araştırmanın önemli bir sınırlılığı ÖG ya da RG çocukların davranışları normal gelişim gösteren akranlarıyla karşılaş̧ırılamamış olmasıdır. Bunun nedeni okul öncesi sınıflarda öğretmen, ÖG ya da RG çocuk ve normal gelişim gösteren bir çocuk için aynı anda üç kamerayla sınıfa girme gerekliliğidir. Okul öncesi sınıflarının yapısı ve etkinliklerin doğası düşünüldügünde, sınıfa üç kamerayla girmenin sınıf düzenini bozması, öğretmen ve çocukların dikkatini dağıtmasına yol açacağından biri ÖG ya da RG çocuğun diğeri öğretmenin davranışlarını kayıt eden iki kamera kullanılmıştır. İleride yapılacak çalışmalarda okul öncesi sınıflarına devam eden ÖG çocukların davranışlarının normal gelişimim gösteren akranlarıyla karşılaştırılması her iki grup çocuğun davranışlarının karşılaştırılmasını sağlayacaktır.

Sonuç olarak, okul öncesinde ÖG çocukların kaynaştırma uygulamalarının yürütüldüğü sınıflarda eğitim almaları birincil tercihtir (MEB, 2006, 2014). MEB'in verilerine göre okul öncesi kaynaştırma uygulamalarına yönlendirilen ÖG çocuk sayısı 2014-2015 dönemi için 304 iken (Milli Eğitim İstatistikleri: Örgün Eğitim: 2014-2015), 2015-2016 için 1.399 olarak belirlenmiştir (Milli Eğitim İstatistikleri: Örgün Eğitim: 2015-2016). Bu sayılar ülkemizde halen çok az sayıda ÖG küçük çocuğun okul öncesi kurumlara devam ettiğini göstermektedir. Daha önce de açıklandığı gibi bunun nedeni öğretmenlerin ve yöneticilerin bu çocukların davranışları ve özelliklerine ilişkin yanlış beklentileri nedeniyle çocukları okul öncesi kurumlarda istememeleri olabilir. Oysa küçük bir grupla da yapılmış olsa, bu çalışmada ÖG ya da RG çocukların problem davranışlarının az olduğu, akranları ve öğretmenleri ile etkileşim kurdukları belirlenmiş̧ir. Bu nedenle okul öncesi öğretmen ve yöneticilerinin kaynaştırma ve ÖG çocukların özellikleri hakkında bilgilendirilmelerinin daha gerçekçi beklentilere yol açabileceği, böylece daha sonra kaynaştırma uygulamalarına katılan ÖG çocukların sayılarının da artabileceği düşünülmektedir. Ayrıca okul öncesi kurumlara devam eden ÖG çocukların ve öğretmenlerinin 
davranışlarını inceleyen araştırmaların artması bu davranışları yordayan değişkenlerin belirlenerek öğretmen ve çocuklar için geliştirilecek olan müdahale programlarının içeriklerinin oluşturulmasına temel oluşturabilecektir.

\section{Kaynaklar}

Akalın, S. (2007). Illköğretim birinci kademedeki sınıf öğretmenleri ile kaynaştırma öğrencisi olan ve olmayan ögrencilerin sınıf içi davranışlarının incelenmesi (Yayınlanmamış yüksek lisans tezi). Ankara Üniversitesi, Eğitim Bilimleri Enstitüsü, Ankara, Türkiye. http://tez.yok.gov.tr/UlusalTezMerkezi adresinden elde edilmiştir. (Tez No. 234603)

Akalın, S., Demir, Ş., Sucuoğlu, B., Bakkaloğlu, H., \& İşcen, F. (2014). The needs of inclusive preschool teachers about inclusive practices. Eurasian Journal of Educational Research, 54, 39-60.

Alberto, P. A., \& Troutman, A. C. (2010). Applied behavior analysis for teachers (9th ed.). Columbus: Ohio Merrill.

Allen, K. E., \& Cowdery, G. E. (2015). The exceptional child. Inclusion in early childhood education (8th ed.). Belmont, CA: Delmar Cengage Learning.

Anderson, K. M. (2007). Differentiating instruction to include all students. Preventing School Failure, 51(3), 4954.

Arnold, D. H., McWilliams, L., \& Arnold, E. H. (1998). Teacher discipline and child misbehavior in day care: Untangling causality with correlational data. Developmental Psychology, 34(2), 276-287.

Aykır, T., \& Çifci-Tekinarslan, İ. (2012). Okul öncesi dönemdeki zihinsel yetersizliği olan ve olmayan çocukların sosyal becerileri ve problem davranışlarının karşılaştırılması. Kastamonu Eğitim Dergisi, 20(2), 627-648.

Baker, B. L., Blacher, J., Crnic, K. A., \& Edelbrock, C. (2002). Behavior problems and parenting stress in families of three-year-old children with and without developmental delays. American Journal on Mental Retardation, 107(6), 433-444.

Birch, S. H., \& Ladd, G. W. (1998). Children's interpersonal behaviors and the teacher-child relationship. Developmental Psychology, 34(5), 934-946.

Bossaert, G., Colpin, H., Pijl, S. J., \& Petry, K. (2011). Truly included? A literature study focusing on the social dimension of inclusion in education. International Journal of Inclusive Education, 17(1), 60-79.

Bronson, B., Hauser-Cram, P., \& Erickson-Warfield, M. (1995). Classroom behaviors of preschool children with and without developmental disabilities. Journal of Applied Developmental Psychology, 16, 371-390.

Bruns, D. A., \& Mogharreban, C. C. (2007). The gap between beliefs and practices: Early childhood practitioners' perceptions about inclusion. Journal of Research in Childhood Education, 21(3), 229-241.

Buell, M. J., Hallam, R., Gamel-McCormick, M., \& Scheer, S. (1999). A survey of general and special education teachers' perceptions and in-service needs concerning inclusion. International Journal of Disability, Development and Education, 46(2), 143-156.

Carta, J. J., Greenwood, C. R., \& Atwater, J. B. (1985). ESCAPE: Eco-behavioral system for complex assessments of preschool environments. Unpublished manual. Kansas City: University of Kansas, Bureau of Child Research, Juniper Gardens Children's Project. 
Casey, A. M., \& McWilliam, R. A. (2008). Graphical feedback to increase teachers' use of incidental teaching. Journal of Early Intervention, 30(3), 251-268.

Chang, Y. C., Shih, W., \& Kasari, C. (2016). Friendships in preschool children with autism spectrum disorder: What holds them back, child characteristics or teacher behavior? Autism, 20(1), 65-74.

Clunies-Ross, P., Little, E., \& Kienhuis, M. (2008). Self-reported and actual use of proactive and reactive classroom management strategies and their relationship with teacher stress and student behavior. Educational Psychology, 28(6), 693-710.

Conroy, M. A., \& Brown, W. H. (2004). Early identification, prevention, and early intervention with young children at risk for emotional or behavioral disorders: Issues, trends, and a call for action. Behavioral Disorders, 29(3), 224-236. Retrieved from http://www.jstor.org/stable/23889471

Cotton, K. (1988). Monitoring student learning in the classroom. Northwest Regional Educational Laboratory. Retrieved from http://educationnorthwest.org/sites/default/files/monitoring-student-learning.pdf

Craig-Unkefer, L. A., \& Kaiser, A. P. (2002). Improving the social communication skills of at-risk preschool children in a play context. Topics in Early Childhood Education, 22(1), 3-13.

Crane-Mitchell, L., \& Hedge, A.V. (2007). Belief and practices of in-service preschool teachers in inclusive settings: Implications for personnel preparation. Journal of Early Childhood Teacher Education, 28(4), 353-366.

Çifci, İ., Yıkmış, A., \& Akbaba-Altun, S. (2001). Kaynaştırma sınıflarında çalışan öğretmenlerin kaynaştırılmış öğrencilere yönelik pekiştireç kullanma durumlarının belirlenmesi. XI. Ulusal Özel Eğitim Kongresi serbest bildiri. Konya: Eğitim Kitapevi Yayınları, 217-229.

Dias, P. C., \& Cadime, I. (2016). Effects of personal and professional factors on teachers' attitudes towards inclusion in preschool. European Journal of Special Needs Education, 31(1), 111-123.

Eiserman, W. D., Shisler, L., \& Healey, S. (1995). A community assessment of preschool providers' attitudes toward inclusion. Journal of Early Intervention, 19(2), 149-167.

Erbaş, D., Kırcaali-İftar, G., \& Tekin-İftar, E. (2004). Işslevsel değerlendirme. Davranış sorunlarıyla başa çıkma ve uygun davranışlar kazandırma süreci. Ankara: Kök Yayıncılık.

File, N., \& Kontos, S. (1992). Indirect service delivery through consultation: Review and implications for early intervention. Journal of Early Intervention, 16(3), 221-233.

Gal, E., Schreur, N., \& Engel-Yeger, B. (2010). Inclusion of children with disabilities: Teachers' attitudes and requirements for environmental accommodations. International Journal of Special Education, 25(2), 89-99.

Gemmel-Crosby, S., \& Redditi-Hanzlik, J. (1994). Preschool teachers' perceptions of including children with disabilities. Education and Training in Mental Retardation and Developmental Disabilities, 29(4), 279290.

Gettinger, M., Stoiber, K. C., Goetz, D., \& Caspe, E. (1999). Competencies and training needs for early childhood inclusion specialists. Teacher Education and Special Education, 22(1), 41-54.

Greenwood, C. R., \& Carta, J. J. (1987). An ecobehavioral analysis of instruction within special education. Focus on Exceptional Children, 19(9), 1-12.

Gunter, P. L., \& Jack, S. L. (1994). Effects of challenging behaviors of students with EBD on teacher instructional behavior. Preventing School Failure, 38(3), 35-39. 
Guralnick, M. J. (1999). Family and child influences on the peer-related social competence of young children with developmental delays. Mental Retardation and Developmental Disabilities, 5(1), 21-29.

Guralnick, M. J. (2001). Social competence with peers and early childhood inclusion: Need for alternative approaches. In M. J. Guralnick (Eds.), Early childhood inclusion: Focus on change (pp. 481-502). Baltimore, MD: Paul H Brookes Pub Co.

Guskey, T. R. (2014). Evaluating professional learning. In S. Billett, C. Harteis, \& H. Gruber (Eds.), International handbook of research in professional and practice-based learning (pp. 1215-1235). NY: Springer.

Güner-Yıldız, N. (2015). Teacher and student behaviors in inclusive classrooms. Educational Sciences: Theory \& Practice, $15(1), 177-184$.

Hammarberg, A. (2003). Preschool teachers' perceived control and behaviour problems in children. (Unpublished doctoral thesis). Acta Universitatis Upsaliensis. Comprehensive Summaries of Uppsala Dissertations from the Faculty of Social Sciences 123. 56 pp. Uppsala, ISBN 91-554-5544-1

Hanrahan, J., Goodman, W., \& Rapagna, S. (1990). Preparing mentally retarded students for mainstreaming: Priorities of regular class and special school teachers. American Journal on Mental Retardation, 94(5), 470-474.

Harrop, A., \& Daniels, M. (1986). Methods of time sampling: A reappraisal of momentary time sampling and partial interval coding. Journal of Applied Behavior Analysis, 19(1), 73-77.

Henninger, W. R., \& Gupta, S. S. (2014). How do children benefit from inclusion? In S. S. Gupta, W. R. Henninger, IV, \& M. E. Vinh (Eds.), First steps to preschool inclusion: How to jumpstart your programwide plan (pp. 33-61). Baltimore, MD: Paul H. Brookes Publishing.

Hestenes, L. L., \& Carroll, D. E. (2000). The play interactions of young children with and without disabilities: Individual and environmental influences. Early Childhood Research Quarterly, 15(2), 229-246.

Heward, W. L. (2013). Exceptional children. An introduction to special education (10th ed.). NJ: Pearson.

Huang, H. H., \& Diamond, K. E. (2009). Early childhood teachers' ideas about including children with disabilities in programmes designed for typically developing children. International Journal of Disability, Development and Education, 56(2), 169-182.

Hughes, J. N., Cavell, T. A., \& Willson, V. (2001). Further support for the developmental significance of the quality of the teacher-student relationship. Journal of School Psychology, 39(4), 289-302.

Hundert, J. (2007). Training classroom and resource preschool teachers to develop inclusive class interventions for children with disabilities: Generalization to new intervention targets. Journal of Positive Behavior Interventions, 9(3), 159-173.

Hutchings, J., Daley, D., Jones, K., Martin, P., Bywater. T., \& Gwyn, R. (2007). Early results from developing and researching the Webster-Stratton Incredible Years Teacher Classroom Management Training Programme in North West Wales. Journal of Children's Services, 2(3), 15-26.

Individuals with Disabilities Education Act of 2004 Retrieved May 16, 2016, from https://www.gpo.gov/fdsys/pkg/PLAW-108publ446/html/PLAW-108publ446.htm

Jack, S. L., Shores, R. E., Denny, R. K., Gunter, P. L., DeBriere, T., \& DePaepe, P. (1996). An analysis of the relationship of teachers' reported use of classroom management strategies on types of classroom interactions. The Journal of Behavioral Education, 6(1), 67-87. 
Kahng, S., Ingvarsson, E. T., Quigg, A. M., Seckinger, K. E., \& Teichman, H. M. (2011). Defining and measuring behavior. In W. W. Fisher, C. C. Piazza, \& H. S. Roane (Eds.), Handbook of applied behavior analysis (pp. 113-131). NY: The Guilford Press.

Karnes, M. B., Johnson, L. J., Cohen, T., \& Shwedel, A. (1985). Facilitating school success among mildly and moderately handicapped children by enhancing task persistence. Journal of the Division for Early Childhood, 9(2), 151-161.

Kern, L., Delaney, B., Clarke, S., Dunlap, G., \& Childs, K. (2001). Improving the classroom behavior of students with emotional and behavioral disorders using individualized curricular modifications. Journal of Emotional and Behavioral Disorders, 9(4), 4239-4247.

Lovell, R. W., \& Reiss, A. L. (1993). Dual diagnoses. Psychiatric disorders in developmental disabilities. Pediatric Clinics of North America, 40(3), 579-592.

MacFarlane, K., \& Woolfson, L. M. (2013). Teacher attitudes and behavior toward the inclusion of children with social, emotional and behavioral difficulties in mainstream schools: An application of the theory of planned behavior. Teaching and Teacher Education 29(1), 46-52.

Malmskog, S., \& McDonnell, A. P. (1999). Teacher-mediated facilitation of engagement by children with developmental delays in inclusive preschools. Topics in Early Childhood Special Education, 19(4), 203 216.

Martin, P. A., Daley, D., Hutchings, J., Jones, K., Eames, C., \& Whitaker, C. J. (2010). The Teacher-Pupil Observation Tool (T-POT) development and testing of a new classroom observation measure. School Psychology International, 31(3), 229-249.

Marzano, R. J., \& Marzano, J. S. (2003). The key to classroom management. Educational Leadership, 61(1), 617.

McDermott, P. A. (1993). National standardization of uniform multisituational measures of child and adolescent behavior pathology. Psychological Assessment, 5(4), 413-424.

McWilliam, R. A., \& Bailey, D. B. Jr. (1995). Effects of classroom social structure and disability on engagement. Topics in Early Childhood Special Education, 15(2), 123-147.

McWilliam, R. A., Trivette, C. M., \& Dunst, C. J. (1985). Behavior engagement as a measure of the efficacy of early intervention. Analysis and Intervention in Developmental Disabilities, 5(1), 59-71.

Milli Eğitim Bakanlığı (2006). Özel Eğitim Hizmetleri Yönetmeliği, 31.05 .2006 tarihli, 26184 sayılı Resmi Gazete.

Milli Eğitim Bakanlı̆̆ı (2014). Okul Öncesi Ĕ̆itim ve İlköğretim Kurumları Yönetmeliği, 26.09.2014 tarihli, 29072 say1lı Resmi Gazete.

Merrell, K. W., \& Holland, M. L. (1997). Social-emotional behavior of preschool-age children with and without developmental delays. Research in Developmental Disabilities, 18(6), 393-405.

Milli Eğitim İstatistikleri: Örgün Eğitim: 2014-2015. T.C. Millî Eğitim Bakanlığı Strateji Geliştirme Başkanlı̆̆ı. http://sgb.meb.gov.tr/istatistik/meb_istatistikleri_orgun_egitim_2014_2015.pdf adresinden 10 Nisan 2016 tarihinde erişilmiştir.

Milli Eğitim İstatistikleri: Örgün Eğitim: 2015-2016. Ankara: T.C. Millî Eğitim Bakanlı̆̆ı Strateji Geliştirme Başkanlığı.

http://sgb.meb.gov.tr/meb_iys_dosyalar/2016_03/30044345_meb_istatistikleri_orgun_egitim_2015_201 6.pdf adresinden 10 Nisan 2016 tarihinde erişilmiştir. 
O'Leary, K. D., \& O'Leary, S. G. (1972). Classroom management: The successful use of behavior modification. New York: Pergamon Press Inc.

Odom, S. L., \& McEvoy, M. A. (1990). Mainstreaming at the preschool level: Potential barriers and tasks for the field. Topics in Early Childhood Special Education, 10(2), 48-61.

Parker, C. (2011). Attitudes and perceptions of early childcare professionals in community-based programs in regard to inclusion of children with disabilities. (Unpublished master's thesis). Honors College of the University of Southern Mississippi, Department of Child and Family Studies, Mississippi, USA.

Porter, L. (2002). Educating young children with additional needs. Australia: Allen \& Unwin.

Sazak-Pınar, E., \& Güner-Yıldız, N. (2013). Öğretmenlerin özel gereksinimli olan ve olmayan öğrencilerin akademik ve sosyal davranışları için kullandıkları onaylama ve onaylamama davranışlarının incelenmesi. Educational Sciences: Theory \& Practice, 13(1), 541-556.

Schepis, M. M., Reid, D. H., Ownbey, J., \& Parsons, M. B. (2001). Training support staff to embed teaching within natural routines of young children with disabilities in an inclusive preschool. Journal of Applied Behavior Analysis, 34(3), 313-327.

Sharma, U., Forlin, C., Loreman, T., \& Earle, C. (2006). Pre-service teachers' attitudes, concerns and sentiments about inclusive education: An international comparison of novice pre-service teachers. International Journal of Special Education, 21(2), 80-93.

Shores, R. E., \& Wehby, J. H. (1999). Analyzing the classroom social behavior of students with EBD. Journal of Emotional and Behavioral Disorders, 7(4), 194-199.

Stanton-Chapman, T. L., \& Brown, T. S. (2015). A strategy to increase the social interactions of 3-year-old children with disabilities in an inclusive classroom. Topics in Early Childhood Special Education, 35(1), 4-14.

Sucuoğlu, B., Bakkaloğlu, H., Akalın, S., Demir, Ş., \& İşcen-Karasu, F. (2015). The effects of the Preschool Inclusion Program on teacher outcomes in Turkey. Journal of Early Childhood Teacher Education, 36(4), 324-341.

Sutherland, K. S., Conroy, M. A., Vo, A., Abrams, L., \& Ogston, P. (2012). An initial evaluation of the teacherchild interaction direct observation system: Measuring teacher-child interaction behaviors in classroom settings. Assessment for Effective Intervention, 39(1), 12-23.

Teach For America (2011). Instructional planning \& delivery. Retrieved from http://www.teachingasleadership.org/sites/default/files/Related-Readings/IPD_2011.pdf on July 1st, 2016.

Tekin-İftar, E. (2012). Eğitim ve davranış bilimlerinde tek denekli araştırmalar. Ankara: Türk Psikoloji Derneği.

Tekin-İftar, E., \& Kırcaali-İftar, G. (2004). Özel eğitimde yanlışsız öğretim yöntemleri. Ankara: Nobel Yayın Dă̆ıtım.

Tomal, D. R. (2010). Action research for educators. United Kingdom: Rowman \& Littlefield Education.

Tsao, L., Odom, S. L., \& Brown, W. B. (2001). Code for active student participation and engagement-Revised (CASPER III): A training manual for observers. Bloomington, IN: Indiana University.

Wolery, M. (2011). Intervention research: The importance of fidelity measurement. Topics in Early Childhood Special Education, 31(3), 155-157. 


\title{
In-Class Behaviors of Teachers and Children with Special Needs or Risk Group in Inclusive Preschool Classrooms*
}

\author{
Şeyda Demir ${ }^{* *}$ \\ Ankara University
}

\begin{abstract}
Since inclusion provides the least restrictive environment (File \& Kontos, 1992; IDEA, 2004) it is considered as the best practice for children with special needs (SN) (Odom \& McEvoy, 1990). However preschool teachers' education is not sufficient to work in inclusion (Akalın et al., 2014; Buell et al., 1999; Bruns \& Mogharberran, 2007; Crane-Mitchell \& Hedge, 2007; Gettinger et al., 1999; Sharma et al., 2006). If children have high levels of impairments and problem behaviors teachers would like to refer them to special education classrooms (Gemmel-Crosby \& Redditi-Hanzlik, 1994; MacFarlane \& Woolfson, 2013). Some preschool teachers have positive some have negative attitudes towards inclusion (Crane-Mitchell \& Hedge, 2007; Dias \& Cadime, 2016; Eiserman et al., 1995; Gal et al., 2010; Huang \& Diamond, 2009; Parker, 2011).
\end{abstract}

Problem behaviors of children with SN are higher (Aykır \& Çifci-Tekinarslan, 2012; Baker et al., 2002; Merrell \& Holland, 1997) and their social interactions are different than their peers without SN (Porter, 2002). Problem behaviors negatively affect interactions with teachers (Jack et al., 1996) teachers' classroom management (Arnold et al., 1998; Hammerberg, 2003), and friendships with peers (Erbaş et al., 2004). Impairments in social interactions increase problem behaviors (Craig-Unkefer \& Kaiser, 2002), and rejection by

\footnotetext{
*This study was produced from the author's Ph.D. thesis which was advised by Prof. N. Bülbin Sucuoğlu at the Institute of Educational Sciences at Ankara University. This study was part of the project supported by Grant 12B6055002 from the Ankara University Scientific Research Projects.

${ }^{* *}$ Corresponding Author: Res. Assist., Ph.D., Ankara University, Faculty of Educational Sciences, Department of Special Education, Ankara, Turkey. E-mail: sedemir@ankara.edu.tr
} 
peers (Guralnick, 1999, 2001). When problem behaviors are excessive teachers use reactive methods (Conroy \& Brown, 2004) which negatively affect their relationship with children with SN (Clunies-Ross et al., 2008). Children with SN show impairments in engagement also (McWilliam \& Bailey, 1995) which means the duration of interacting with the environment (McWilliam et al., 1985). Engaging in table-top activities (TTA) and free play (FP) increases development of children (Bossaert ve diğ., 2011; Karnes et al., 1985).

Interactions with teachers during preschool increase development of children with SN (Birch \& Ladd, 1998; Hestenes \& Carroll, 2000; Hughes et al., 2001), but teachers interact less positively with them (Gunter \& Jack, 1994; Shores \& Wehby, 1999). When teachers reinforce them less it negatively affects their relationship and learning environment (Hutchings et al., 2007).

In Turkey there are studies conducted to examine in-class behaviors of elementary students with SN and their teachers (Akalın, 2007; Çifci et al., 2001; Güner-Yıldız, 2015; Sazak-Pınar \& Güner-Yıldız, 2013). In only one study effects of a preschool inclusion program on teachers were examined (Sucuoğlu et al., 2015). The purpose of this study was to examine behaviors of children with SN, risk group (RG) and their teachers in inclusive preschool classrooms.

\section{Method}

This study is a descriptive research which was conducted in survey method. The study group consisted of 17 teachers and their students with SN or RG in an independent preschool in Ankara, Turkey. All teachers are women and they are graduates of four years of college. Their mean age is 31.29 , their teaching experience is six months-30 years, and their acquaintance with children with $\mathrm{SN}$ is one-20 months. Ten children with $\mathrm{SN}$ are boys, 7 are girls. The mean age of children with SN is 66 months, RG is 55 months. Nine are diagnosed with SN, eight are RG according to teacher opinions. RG means serious developmental difference than normal development (Heward, 2013). Teachers are accepted as reliable sources for identifying children with RG (McDermott, 1993).

The data collection tools are the Information Form, Teacher Behaviors Observation Form, and Child Behaviors Observation Form. While developing observation forms, previous observational research conducted in inclusive preschools were examined (Carta et al., 1985; Hundert, 2007; Malmskog \& McDonnell, 1999; Martin et al., 2010; Schepis et al., 2001; Sutherland et al., 2012; Tsao et al., 2001). For teachers a) interactions with children with SN or RG (partial-interval recording), b) positive behaviors (frequency of approval of social and academic behaviors+offering learning opportunities), and c) negative behaviors towards children with $\mathrm{SN}$ or RG (frequency of disapproval behaviors) were included. For children a) interactions with peers (partial-interval recording), positive interactions (frequency of initiating interactions+responding to interactions positively), c) negative interactions with peers and teachers (frequency of initiating interactions+responding to interactions negatively), d) problem behaviors (partial-interval recording), and e) on-task behaviors (whole-interval recording) were identified.

Two cameras recorded teacher and child behaviors during 30 minute TTA and FP in each classroom. Percentages for behaviors observed by partial- and whole-interval recording and frequencies for the rest of the behaviors were calculated. Intra- and inter-coder reliabilities were calculated and found to be higher than the criterion (80\%) to accept that the data were observed reliably (Casey \& McWilliam, 2008; Tekin-İftar, 2012).

\section{Results}

Teachers' interactions (approximate duration by partial-interval recording) with children with SN or RG was found to be $16.40 \%$ in TTA and $14.26 \%$ in FP. Teachers' positive behaviors towards children with SN or RG (frequency for approval of social and academic behaviors+offering learning opportunities) were 21 for TTA and 18 for FP on average. Negative behaviors (frequency of disapproval behaviors) were very few (for TTA 1.70 and FP 1.29 on average). Interactions of children with SN or RG with their peers (approximate duration by partial-interval recording) was $8.46 \%$ for TTA and $20.31 \%$ for FP. Their positive interactions with peers and 
teachers were 18 times for TTA and 25 times for FP on average, whereas their negative interactions were 7 times for TTA and 9 times for FP on average. Their problem behaviors for TTA and FP were 32.37\% and 29.48\% respectively. On-task behaviors were $44.02 \%$ for TTA. Children with SN and RG did not significantly differ in any of the variables observed.

\section{Discussion and Conclusion}

The finding that children with SN and RG show problem behaviors in TTA may indicate that teachers do not know how to adapt and modify activities according to characteristics of children with SN and RG (Kern et al., 2001). The researcher collected anecdotal data (Tomal, 2010) in addition to observations. Informal interviews with teachers suggested teachers did not structure FP and let children play by themselves. This may have resulted in findings that children with SN and RG initiated and responded to initiations more but their duration of interactions with teachers were low during FP.

Children who have high levels of intellectual impairments may exhibit high levels of problem behaviors (Lovell \& Reiss, 1993). A study with elementary school children showed students with SN show low levels of problem behaviors than and similar levels of on-task behaviors to their peers without SN (Akalın, 2007). In Turkey children with low levels of impairments are placed in preschool inclusion (MEB, 2014), that might be the reason for the finding that children with SN and RG showed few problem behaviors.

\section{Önerilen Atıf Sekli}

Demir, Ş. (2016). Okul öncesi kaynaştırma sınıflarındaki öğretmenlerin, özel gereksinimli ve risk grubu çocukların sınıf içi davranışlarının incelenmesi. Ankara Üniversitesi Eğitim Bilimleri Fakültesi Özel Ĕ̈itim Dergisi, 17(2), 141-162. 